\title{
Effects of Staple-based Mungbean Diets on the Physical and Biochemical Characteristics of School Children (5-12 Years) in Selected Orphanage Homes in Imo State
}

\author{
Agugo Udodiri Agatha ${ }^{1,}$, , Asinobi Chinagorom Onyemaechi ${ }^{2}$, Afam-Anene Olivia Chinyere ${ }^{2}$ \\ ${ }^{1}$ Department of Nutrition and Dietetics, School of Sciences, Imo State Polytechnic, Umuagwo, Ohaji, Nigeria \\ ${ }^{2}$ Department of Nutrition and Dietetics, Faculty of Health Sciences, Imo State University, Owerri, Nigeria
}

Email address:

udodiriagugo@yahoo.com (A. U. Agatha)

${ }^{*}$ Corresponding author

\section{To cite this article:}

Agugo Udodiri Agatha, Asinobi Chinagorom Onyemaechi, Afam-Anene Olivia Chinyere. Effects of Staple-based Mungbean Diets on the Physical and Biochemical Characteristics of School Children (5-12 Years) in Selected Orphanage Homes in Imo State. Journal of Food and Nutrition Sciences. Vol. 8, No. 4, 2020, pp. 96-102. doi: 10.11648/j.jfns.20200804.14

Received: June 30, 2020; Accepted: July 14, 2020; Published: July 28, 2020

\begin{abstract}
The study investigated the effect of staple-based mungbean diets on the physical and biochemical characteristics of school children (5-12 years) in selected orphanage homes in Imo State. Experimental research design was employed. Five (5) government approved homes were purposively selected, and a total of 95 subjects randomly sampled to the experimental (50) and control (45) groups across the homes. Staple-based mungbean diets replaced one of the daily three square meals of subjects in the experimental groups for a period of six months. After intervention, Body Mass Index of male $\left(16.7 \mathrm{Kg} / \mathrm{m}^{2}\right.$ to $\left.16.4 \mathrm{Kg} / \mathrm{m}^{2}\right)$ and female $\left(17.5 \mathrm{Kg} / \mathrm{m}^{2}\right.$ to $\left.16.9 \mathrm{Kg} / \mathrm{m}^{2}\right)$ subjects in the experimental groups reduced while Body Mass Index of male $\left(17.8 \mathrm{Kg} / \mathrm{m}^{2}\right.$ to $\left.18.7 \mathrm{Kg} / \mathrm{m}^{2}\right)$ and female $\left(15.9 \mathrm{Kg} / \mathrm{m}^{2}\right.$ to $\left.16.8 \mathrm{Kg} / \mathrm{m}^{2}\right)$ subjects in the control groups slightly increased, though not significant $(\mathrm{p}<0.05)$. Generally, biochemical characteristics of subjects in the experimental and control groups improved after six months. Significant $(\mathrm{p}<0.05)$ improvement was observed in the hemoglobin $(6.7 \%)$, serum iron $(29.8 \%)$ and TIBC $(4.3 \%)$ of subjects in the experimental group, while the improvement observed in the hemoglobin $(2.8 \%)$, serum iron $(10.9 \%)$, and TIBC $(1.1 \%)$ levels of subjects in the control group were not significant. Serum zinc level of subjects in the experimental (43.2\%) and control (12.9\%) groups significantly improved and clinical signs (skin rashes) significantly reduced $(100 \%)$. It could be concluded that staple-based mungbean diets probably improved the physical and biochemical characteristics of school children studied. Therefore, are recommended for the feeding of growing children especially the school aged (5-12 years).
\end{abstract}

Keywords: Staple-based, Mungbean Diets, Physical, Biochemical, Intervention

\section{Introduction}

Globally, the problem of malnutrition remains severe as the world is not on track to achieve the targets it has set. Malnutrition in all forms remain unacceptably high across all regions of the world [1]. Malnutrition is widespread in both rural and urban communities of Nigeria and low-income group is more vulnerable to chronic food shortages, unbalanced nutrition, erratic food supply, poor quality foods, high food costs and even total lack of food [2]. This phenomenon as given rise to undernutrition (both macro and micro nutrient deficiency) among all age groups including the school age children. The impact of undernutrition on the cognitive ability of growing children may lead to poor school achievement in life if neglected.

School age children are children between 5-12 years who grow rapidly and can be active and need diet providing adequate energy and nutrients for development [3]. School age children constitute an important segment of any society as they represent $20 \%$ to $30 \%$ of the population [4]. Growing children are required to eat a variety of foods to ensure optimal intake of essential nutrients. Nevertheless, school children are most of the time neglected as far as food and adequate nutrition is concerned [5]. Evidence from study 
conducted by the United Nations Children's Fund [6], shows that there is no clear data on the actual nutritional status of school age children in developing countries. This is because most researchers have focused on under-five children. It has been assumed that by school age a child has survived the most critical period and is no longer vulnerable [7]. This neglect if not addressed could lead to poor food intake, repeated infections and poor nutritional status among the school age children. In order to adopt a life cycle approach in solving nutritional problems in the society, it is important to monitor the nutritional status of the school age and the adolescent, especially with the emerging double burden of global malnutrition problems [8]. It has been reported that appropriate nutrition is a basic human need that remains unmet for a vast number of children living in Sub-Saharan Africa with the very high rate in countries like Ethiopia and Nigeria [9].

Mungbean is an excellent source of easily digestible protein [10]. Report from previous study shows that mungbean is a nutritious legume, supplying $25 \%$ protein, $61 \%$ carbohydrate, $130 \mathrm{mg}$ calcium, $2.8 \mathrm{mg}$ zinc, and $4.2 \mathrm{mg}$ iron [11]. According to Goplalan et al. [12], in comparison to other pulses, mungbean has been found to be rich in dietary iron. Mungbean provides significant amounts of dietray iron to plant -based diets in developing countries where mungbean is consumed [13]. Mungbean induces less flatulence and is well tolerated by children [14]. The Food and Agricultural Organization in collaboration with the World Health Organization [15], reported that two-third of the world's population depends on cereals or tuber-based diets. This is evidence in the study conducted by Ene-Obong and Ekweagwu [7] where the most frequently consumed staple by rural school age children in Ebonyi state, Nigeria was cassava-based product akpu/fufu and garri, ranking $73.9 \%$ while legume ranked only $11.9 \%$ consumption rate. Mungbean can serve as food substitute to staples (cerealbased, root/ tuber-based crops) consumed in south eastern Nigeria, due to its high protein content and ease of digestibility [16].

In developing countries where resources are limited, there is need for targeted nutrition intervention programmes in order to reduce cost [7]. Food-based approaches have proved to be the most pragmatic and sustainable approach in reducing nutritional deficiencies, especially micronutrient deficiencies [17]. Increasing bioavailability of micronutreint rich foods through processing and developing varieties with increased levels of promoter of food absorption are all foodbased approaches with nutrition objectives [18-19]. Granted, there are many legumes already in existence, dietary diversification is a suitable food based strategy capable of improving nutrient intake. Lack of adequate food and diversified diets may be among the major factors that causes childhood undernutrition. In view of this, traditional cereal and tuber-based diets substituted with mungbean is a form of dietary diversification which can contribute to providing acceptable food complements capable of improving the nutritional status of school age children for productive lifestyle at adult age.

\section{Materials and Methods}

\subsection{Study Area}

The study was conducted with five government approved orphanage homes in the three senatorial (Orlu, Okigwe and Owerri) zones of Imo State, Nigeria.

\subsection{Research Design}

Experimental research design was adopted, subjects (experimental and control groups) were located in each home.

\subsection{Population and Sampling}

The study consist of school age children between 5 to 12 years. A total population of 117 school age (5-12 years) children were located in the selected orphanage homes. The five orphanage homes used for the study were selected through purposive sampling method. Cluster sampling technique was used to select subjects from each home while simple random sampling method was used to select the experimental and the control groups in each home. A total of 95 school age children were selected from the total population following the method of Yamane [20].:

$$
\mathrm{n}=\frac{\mathrm{N}}{1+\mathrm{N}(\mathrm{e})^{2}}
$$

$\mathrm{n}=$ sample size $\mathrm{N}=$ total population; $\mathrm{e}=$ sampling error $[5 \%$ ]

\subsection{Ethical Approval}

A letter of approval was obtained from the Ethical Committee of Imo State University Teaching Hospital (IMSUTH), Orlu, Ministry of Health Owerri and Ministry of Gender and Social Affairs Owerri.

\subsection{Selection Criteria}

Ethical approval letters, and $500 \mathrm{~g}$ of raw mungbean seeds were submitted to the matron in charge of the government approved orphanage homes in Imo State. The homes were given one-week interval to verify the documents and consume the mungbeans. Objective of the experiment was carefully explained to the home authorities to formally seek their consent and cooperation during the feeding trial. After the processes, five homes consented to participate in the study. Furthermore, school age children located in the selected homes were asked very simple questions (in the assent form) to elicited their willingness/refusal to participate in the research. Sampling was strictly based on the assent of the individual child.

\subsection{Motivation/Support}

The Five homes that gave their consent were supplied with food materials such as rice $(50 \mathrm{~kg})$, cowpea $(25 \mathrm{~kg})$, canned 
tomato puree (2 cartons), onions (10 kg), yam (20 sizable tubers), crayfish $(10 \mathrm{~kg})$, dry catfish $(10 \mathrm{~kg})$, salts (5 packets), magi star (2 packets), vegetable oil (10 liters), and raw mungbeans $(20 \mathrm{~kg})$. Mungbean-garri diet was centrally produced and supplied to the homes on demand throughout the period of intervention.

\subsection{Recruitment and Training of Research Assistants}

The research assistants were two staff (cooks) adopted from each home, two undergraduates and an experienced medical laboratory technician. The purpose and objective of the experiment was explained to the research assistants.

\subsection{Data Collection}

\subsubsection{Food Frequency Questionnaire (FFQ)}

The FFQ used for data collection was validated by experts in the Department of Nutrition and Dietetics/Faculty of Health Sciences, Imo State University, Owerri and pre-tested before administering to the home attendants. The FFQ was used to obtain information on the prevailing food consumption pattern of subjects in the different homes.

\subsubsection{Anthropometric Measurement}

Anthropometric indices (weight and height) of the children were taken. Height of each child was measured while standing barefoot on the floorboard with heels of both feet together, touching the base of the vertical board. The toes pointed straight outward at approximately a 60-degree angle. Body weight evenly distributed with both feet flat on the flour. For some children that were not able to assume the correct position on their own, minor adjustment was made by gently lifting their heads up or down until proper alignment was achieved with the eyes looking straight ahead. Once correctly positioned the headboard was lowered on top of the child's head and measurement read and recorded to the nearest $0.1 \mathrm{~cm} \mathrm{[21].}$

Weight of the individual child was taken without shoes and in light clothing, with the use of portable bathroom scale (Camry) to the nearest $0.1 \mathrm{~kg}$ [21].

\subsubsection{Blood Sample Collection}

The procedure of Geisinger Health System [22] was adopted in blood sample collection. Using a $5 \mathrm{ml}$ syringes, 5 $\mathrm{ml}$ of blood was collected from each child, stored in Ethylene Diamine Teraacetic Acid (EDTA) bottles (red and green caps) and transported to Hematology and clinical chemistry laboratory of Imo State Teaching Hospital Orlu within a period of 12 hours. Blood samples were collected before and after the intervention.

\subsubsection{Clinical Examination}

Record of clinical signs (dry rough skin, and skin rashes) observed among the subjects before and after intervention were kept.

\subsubsection{Intervention}

Staple-based mungbean diets [23] and Mungbean-garri diet [24] replaced one of the daily three square meals of subjects in the experimental group for a period of six months.

\subsubsection{Determination of Biochemical Parameters}

The biochemical (hemoglobin, serum iron and TIBC) parameters were determined following the method of International Committee for Standardization in Hematology [25]. While serum zinc was determined using the method introduced by American Public Health Association [26]. Elemental analysis was conducted using Agilent FS240 AA Atomic Absorption Spectrophotometer [26].

\section{Results}

Table 1. Anthropometric indices of subjects in the experimental and control groups.

\begin{tabular}{|c|c|c|c|c|c|c|c|c|c|c|c|c|}
\hline \multirow{3}{*}{ Parameters } & \multicolumn{6}{|l|}{ Male } & \multicolumn{6}{|l|}{ Female } \\
\hline & \multicolumn{3}{|c|}{ Experimental group $(n=27)$} & \multicolumn{3}{|c|}{ Control group $(n=21)$} & \multicolumn{3}{|c|}{ Experimental group $(n=23)$} & \multicolumn{3}{|c|}{ Control group $(n=22)$} \\
\hline & Baseline & End line & p-v & Base line & Endline & p-v & Base line & End line & p-v & Base line & End line & p-v \\
\hline Height & $1.34 \pm 10.1$ & $1.36 \pm 9.2$ & .00 & $1.24 \pm 13.5$ & $1.27 \pm 12.4$ & .29 & $1.34 \pm 10.9$ & $1.39 \pm 0.12$ & .07 & $1.4 \pm 12.1$ & $1.42 \pm 12.1$ & .00 \\
\hline Weight & $30.5 \pm 5.9$ & $30.3 \pm 4.9$ & .86 & $27.3 \pm 7.1$ & $30.2 \pm 3.5$ & .37 & $31.4 \pm 7.5$ & $32.8 \pm 7.7$ & .49 & $31.2 \pm 5.9$ & $33.9 \pm 6.9$ & .01 \\
\hline $\operatorname{BMI}\left(\mathrm{Kg} / \mathrm{m}^{2}\right)$ & $16.7 \pm 1.4$ & $16.4 \pm 3.5$ & .79 & $17.8 \pm 13.1$ & $18.7 \pm 1.8$ & .34 & $17.5 \pm 3.1$ & $16.9 \pm 1.75$ & .66 & $15.9 \pm 2.8$ & $16.8 \pm 3.8$ & .30 \\
\hline
\end{tabular}

Table 2. Mean biochemical parameters of subjects in the experimental and control group.

\begin{tabular}{|c|c|c|c|c|c|c|c|c|}
\hline \multirow{2}{*}{ Parameters } & \multicolumn{5}{|c|}{ Experimental group } & \multicolumn{3}{|c|}{ Control group } \\
\hline & Base line & End line & $\% \mathbf{I}$ & p-value & Base line & End line & $\% \mathbf{I}$ & p-value \\
\hline Haemoglobin (dl/l) & $10.5 \pm 1.41$ & $12.0 \pm 0.91$ & 6.7 & 0.07 & $10.4 \pm 1.6$ & $10.9 \pm 1.6$ & 2.8 & 0.25 \\
\hline Serum iron $(\mu \mathrm{g} / \mathrm{l})$ & $80.8 \pm 51.8$ & $149.5 \pm 41.8$ & 29.8 & 0.04 & $90.3 \pm 68.1$ & $112.6 \pm 71.3$ & 10.9 & 0.52 \\
\hline Serum TIBC & $257.3 \pm 43.9$ & $280.4 \pm 37.4$ & 4.3 & 0.23 & $258.3 \pm 39.4$ & $263.9 \pm 30$ & 1.1 & 0.73 \\
\hline Serum zinc $(\mathrm{mg} / \mathrm{dl})$ & $0.48 \pm 0.09$ & $1.22 \pm 0.64$ & 43.2 & 0.00 & $0.44 \pm 0.07$ & $0.57 \pm 0.2$ & 12.9 & 0.00 \\
\hline
\end{tabular}

Significant at $\mathrm{P}<0.05 ; \% \mathrm{I}=$ Percentage Increase 
Agugo Udodiri Agatha et al:: Effects of Staple-based Mungbean Diets on the Physical and Biochemical

Characteristics of School Children (5-12 Years) in Selected Orphanage Homes in Imo State

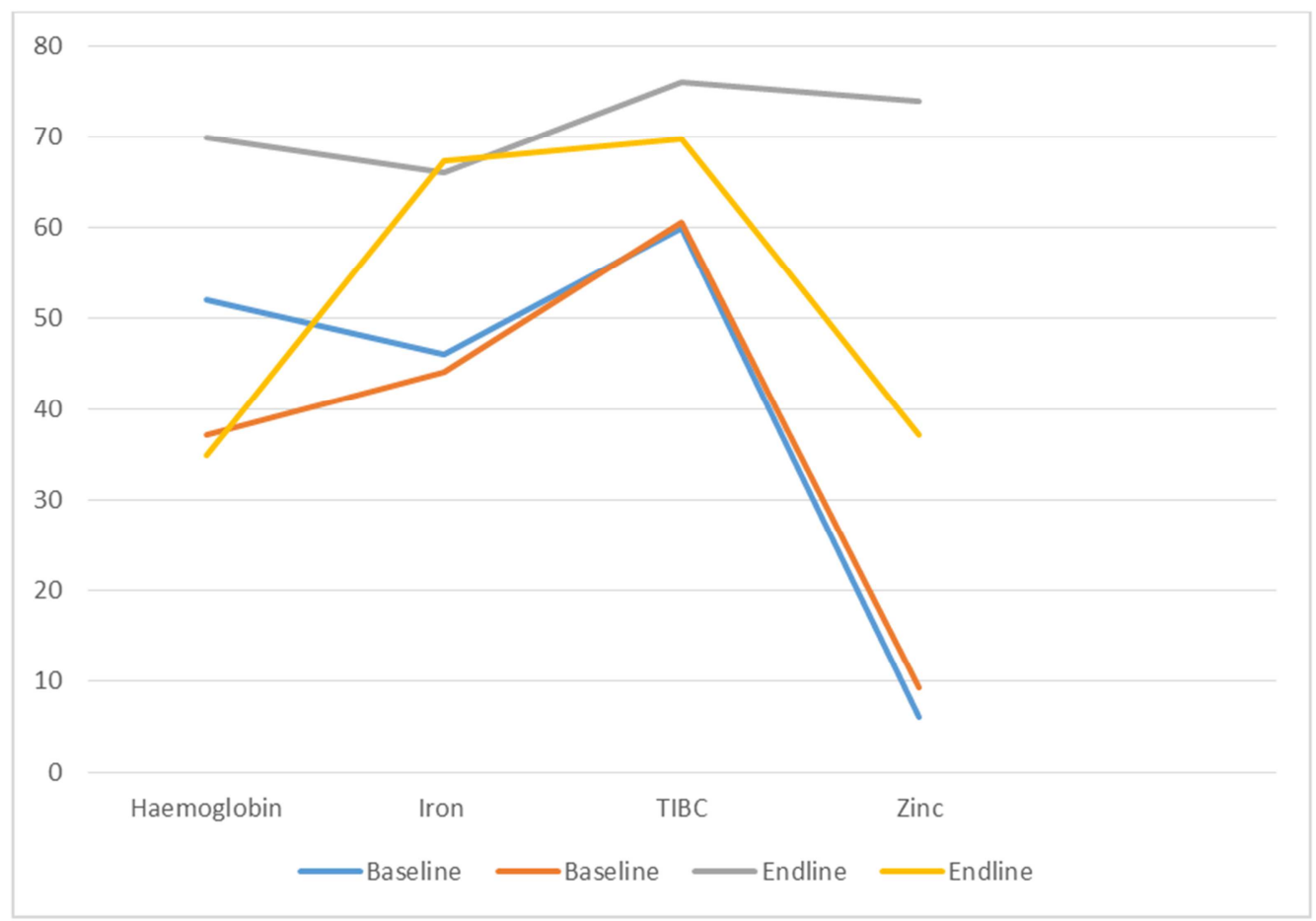

Figure 1. Biochemical characteristics of subjects at base line and end line of the experiment.

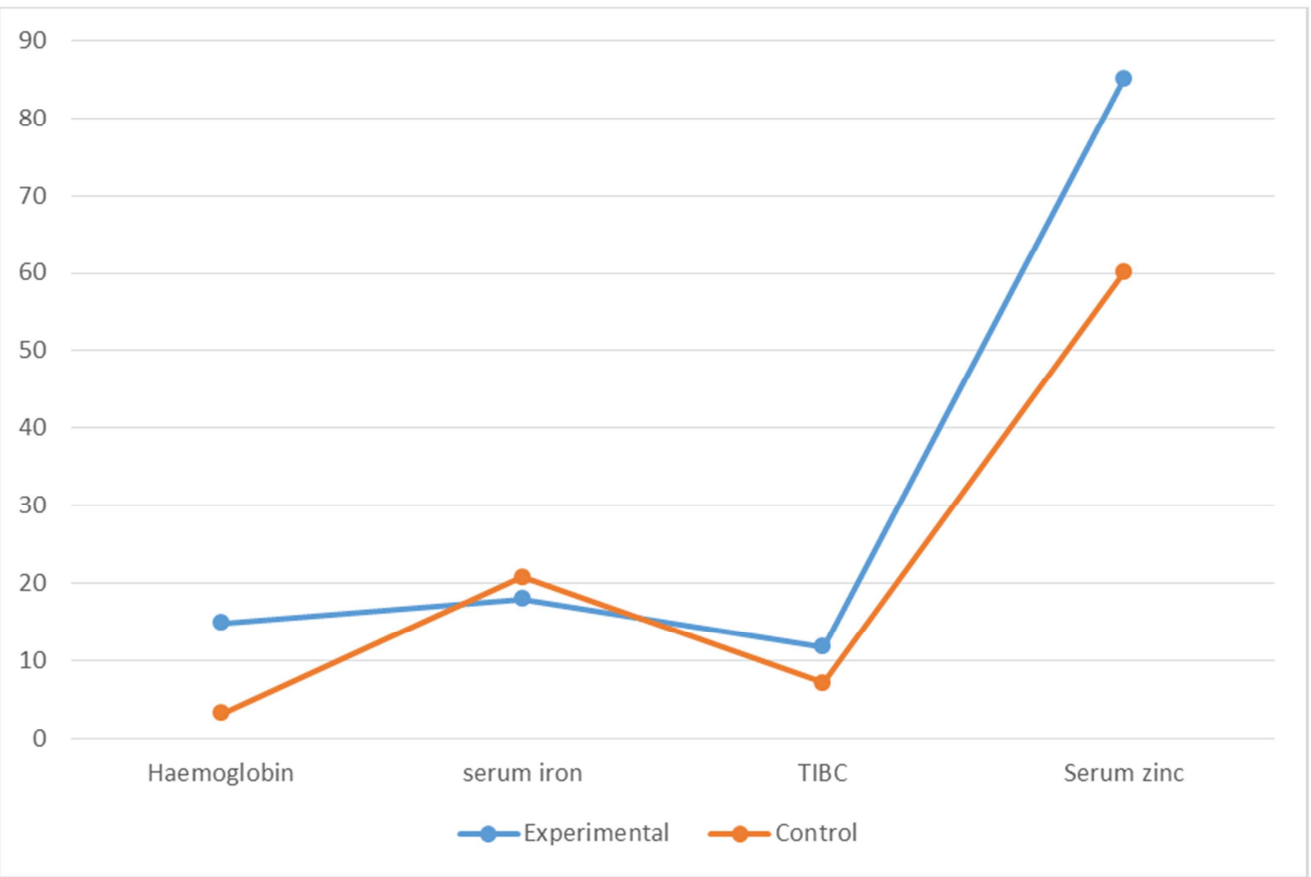

Figure 2. Percentage of subjects within the normal biochemical categories at the end line.

Table 3. Clinical signs observed among the subjects.

\begin{tabular}{lllll}
\hline \multirow{2}{*}{ Signs and symptoms } & Experimental group & & Control group & \\
\cline { 2 - 5 } & $\mathbf{n}(\%)$ & $\mathbf{n}(\%)$ & $\mathbf{n}(\%)$ & $\mathbf{n}(\%)$ \\
\hline Male & Base line & End line & Base line & End line \\
Dry and rough skin & $3(11.1)$ & - & - & - \\
Skin rashes & $6(22.2)$ & - & $1(4.7)$ & - \\
Female & Base line & End line & Base line & End line \\
Dry and rough skin & $1(4.3)$ & - & $2(9)$ & - \\
Skin rashes & - & - & $2(9)$ & - \\
\hline
\end{tabular}




\section{Discussion}

The physical (height and weight) characteristics of the subjects in the experimental group improved significantly after the intervention. The values obtained were within the WHO reference standard for weight and height [27]. This finding is in contrast with the report of Ghate and Kotwal [28], where the mean height and weight record of school children were significantly less than the value reported by National Center for Health Statistics [21]. The BMI status of the male $\left(16.4 \mathrm{~kg} / \mathrm{m}^{2}\right)$ and female $\left(16.9 \mathrm{~kg} / \mathrm{m}^{2}\right)$ subjects in the experimental groups after intervention were within the range reported by [7], among school aged boys (14.77- 17.98 $\left.\mathrm{kg} / \mathrm{m}^{2}\right)$ and girls $\left(14.14-17.98 \mathrm{~kg} / \mathrm{m}^{2}\right)$ in Ebonyi State, Nigeria. According to Fetuga et al. [29], findings from past cross-sectional and prospective epidemiological studies suggest that the WHO BMI cut-offs do not adequately represent the obesity status worldwide.

The prevalence of anaemia (48.1\%) observed at the base line corresponds with the level (49.6\%) reported by Anumudu et al. [30], among children in the south eastern region in Nigeria and in the developing world (12-60\%) [31]. In contrast to this finding, Ukegbu and Aderibigle [32], reported lower $(30 \%)$ prevalence of anaemia among school aged children in Umuahia south local government area, Abia State. The high percentage of anaemia recorded among the subjects at the base line could be attributed to the existing food consumption pattern (high carbohydrate rich foods) in the selected motherless and orphanage homes [33]. After the intervention, very significant $(p<0.05)$ reduction $(31.2 \%)$ in anaemia was observed among the male and female subjects in the experimental groups. The percentage of children within the normal serum iron and TIBC category improved significantly $(\mathrm{p}<0.05)$ among the subjects in the experimental groups after the intervention. The improved serum iron level observed among the subjects may be attributed to the processing (addition of fresh tomatoes, heat treatment and fermentation) methods applied in the preparation of staplebased mungbean diets [23-24].

Based on the recommended standard [34], only very few $(5.3 \%)$ of the subjects falls within the normal zinc level at the base line. After the intervention, percentage of subjects within the normal serum zinc category improved significantly $(\mathrm{p}<0.05)$, serum zinc level $>1.2 \mu \mathrm{g} / \mathrm{dl}$ was also recorded. The prevalence serum zinc deficiency observed among the subjects at the baseline was high compared to the rate reported in other parts of the country, example; a moderate zinc deficiency of $5-30 \%$ have been reported in children and adolescent from different countries [35]. In Mexican, Villalpando et al. [36] observed 19-24\% of serum zinc deficiency among school aged children below 12 years. Sharify et al. [37] reported $13.7 \%$ of zinc deficiency among school aged children $8-11$ years in 23 provinces in Iran. In another research, Thurlow et al. [38] reported a high prevalence of low serum zinc concentration of $57 \%$ among school children aged 6-13 years in North-East Thailand. While only $16 \%$ of zinc deficiency based on dietary zinc intake was found among children aged 5-14 years in New Zealand [39]. Again, the low serum zinc level observed among the subjects could be due the existing food consumption pattern (regular and high consumption of cereals, root and tuber based food products) in the selected homes [33]. According to Golden [40], school children that consumes monotonus meals containing very little animal products, are at high risk of specific deficiencies, especially iron and zinc. Moreover, zinc deficiency has been found to be common in many lower-income countries because their diets are composed primarily of cereals and legumes which contain substantial amounts of phytate a compound known to inhibit zinc absorption [41].

Generally, low percentage of the subjects were affected $(21.5 \%)$ with clinical symptoms at the base line. However, the clinical signs observed among the subjects was significantly $(p<0.05)$ reduced $(100 \%)$ at the end line. The clinical signs (skin rashes) observed among the subjects at the base line may be attributed to the low zinc levels. Among other symptoms, dry and rough skin, dermatitis, and acne are the most common symptoms of zinc deficiency among children [42]. Zinc deficiency is also associated with poor growth, depressed immune function hair loss, increased susceptibility to and severity of infections and neuro behavioural abnormalities [43-44].

\section{Conclusion}

There was high prevalence of anaemia and zinc defficiency among school age children in the orphanage homes studied. The prevailing feeding pattern in the different homes was also poor and unacceptable for feeding growing children.

Daily consumption of staple-based mungbean diets propably boosted the macro and micronutrient intake of school children due to the improvement observed in physical (BMI) and biochemical (hemoglobin, serum iron, serum zinc and TIBC) characteristics of subjects after six months of nutrition intervention.

\section{Recommendation}

The urgent assistance of the government, nongovernmental organizations and well meaning individuals are needed for more nutrition intervention programme in Imo State.

Increasing the consumption of legume based diets especially staple-based mungbean diets will enable school children grow and develop optimally especially in south east Nigeria were plant based foods constitute the major meal of most families. 


\section{References}

[1] UNICEF/World Health Organization (WHO)/World Bank Group (2018). Global Nutrition Report. The burden of malnutrition. Joint child malnutrition estimate. https://globalnutritionreport.org/reports/global-nutrition-report 2018/burden- malnutrition/. Retrieved 09/11/2019.

[2] Abdullateef, U., and Ijaiya, A. (2010). Agricultural trade liberalization and food security in Nigeria. Journal of Economics and International Finance, 2: 299-307.

[3] British Nutrition Foundation (2018). A charity registered in Scotland (Sco40061). www.nutrition.or.uk

[4] ACC/SCN (2012). Second Report on the World Nutrition Situation. Vol. 1. Global and regional results. Geneva Adewara, S. O. and Visser, M. (2011). Use of anthropometric measures to analyze how sources of water and sanitation affect children's health in Nigeria. Environment for Development Discussion Paper Series, pp. 11-20.

[5] Fleck, H. (2001). Introduction to nutrition: The third Edition Macmillan publishing Co. Inc. New York.

[6] UNICEF (1995). The state of the worlds children: focus on nutrition. www.unicef.org/sowc/archive/ENGLISH/The $\%$ state $\% 2$. Retrieved 12/02/2012

[7] Ene-Obong, H. N., and Ekweagwu, E. (2012). Dietary Habits and Nutritional status of rural school age children in Ebonyi State, Nigeria. Nigerian Journal of Nutrition Sciences, 33 (1), 23-30.

[8] International Food Policy Research Institute (2018). 2018 Global food policy report. Washington, DC: International Food Policy Research Institute. https://doi.org/10.2499/9780896292970.

[9] Adewara, S. O. and Visser, M. (2011). Use of anthropometric measures to analyze how sources of water and sanitation affect children's health in Nigeria. Environment for Development Discussion Paper Series, pp. 11- 20.

[10] Satayanamyana, A. P., Seenaiah, M. U., Rahman, V., and Naidu N. U. (1996). Improvement of mungbean for rice fallows, P. 137. In: Ashana A. M and D. H Kim (eds). Recent advances in Mungbean research Kanpar, India. India Institute of Pulse Research. Pp 210.

[11] Agugo, U. A and Onimawo A. I. (2009). Effect of heat treatment on the Nutritional Value of mungbean. Nigerian Journal of Nutrition Science, 30 (2), pp. 10-15.

[12] Gopalan, C., Rama B. V., Sastri, and Balasubramanian S, C. (2000). Nutritive value of Indian foods. Indian Council of Medical Research, 5, 10-15.

[13] Vijayalakshmi, P., Amirthaveni S., and Devadas, R. P. (2001). Possibilities of increasing bioavailability of iron from mungbean and study on the effects of its supplementation on children and women. Project Report. Coimbatore, India: Avinashilingam Institute for Home Science and Higher Education for Women, Coimbatore, India

[14] Pal, M., Brahmachary, K. L and Ghosh, M. (2010). Comparative studies on physicochemical and biochemical characteristics of scented and non -scented strains of mungbean (Vigna radiata) of Indian origin. Legume Research. 33: $1-9$

[15] FAO/WHO (1998). Requirements of Vitamin A, Iron, Folate and Vitamin B12, Report of a jiont FAO/WHO Expert Consultation. (Food and Nutrition Series, No. 23) FAO, Rome

[16] Axe, F. (2017). Mung Beans Nutrition \& Its Big Benefits. Available at: https://draxe.com/mung-beans-nutrition/. Retrieved 06/04/2017

[17] Ramakrishan, M. N., Ray-yuYang Warwick J. E., Dil, T. P., Jacquelin d'AHughes and Keating, J. D. H. (2013). Biofortification of mungbean (Vigna radiata) as a whole food to enhance health. Journal of Science, Food and Agriculture. 93 (8): 1805-13.

[18] Ruel, M. (2001). Food-based strtegies Help Reduce Vitamin A and Iron deficiencies?International Food Policy Research Institute: Washington.

[19] Yang, R. Y., Hanson, P. M., and Lumpkin, T. A. (2007). Better health through horticulture-AVRDC's approach to improve nutrition of the poor. Acta Horticulturae, 744, 71-77.

[20] Taro Yamane (1967). Statistics, An Introductory Analysis, 2nd Ed., New York: Harper and Row.

[21] NCHS (2011). National Center for Health Statistics, 311 Toledo Road Room 5419 Hyattsville, MD 2078. 1 (800) 232463.

[22] Geisinger Health System (2000-2014). Geisinger Foundation. www.geisinger.org. Accessed 16/08/2018

[23] Agugo, U. A, Asinobi C. O and, Afam-Anene O. (2019). Evaluating the nutritional and sensory qualities of substituted Staple-Based-Mung bean diets. International Journal of Food Science and Nutrition. Vol 4 (2). Pp 42-48.

[24] Agugo, U. A, Asinobi C. O and, Afam-Anene O. (2019). Investigating the nutritional, sensory and Storage qualities of substituted-mungbean garri diet. Journal of Food Technology and preservation, 3 (1): 5-10.

[25] International Committee for Standardization in Haematology. (1987). (Iron Panel). British Journal of Haematology. 38: 291

[26] American Public Health Association (1998). 3111B, Direct Air- Acetylene Flame Method, Standard Methods for the examination of metals in blood 20th Edition, APHA, AWWA, WEF 1178-1180.

[27] World Health Organization. (2007). Child growth Standards. Available at http://www.who.int/growtref/en.2007. Retrieved $12 / 02 / 2012$

[28] Ghate, P., and Kotwal, D. (2014). Nutritional status and dietary pattern of 7-9 years school going children in India and Ethiopia. The International Journal of Humanities and Social Studies. (ISSN 2321 -9203) www.theijhss.com

[29] Fetuga, M. B., Ogunlesi, T. A, Adekambi, A. F and Alabi, A. O (2014). Nutritional status of semi -urban Nigerian school children using 2007 WHO Reference population. West African Journal of Medicine, 30 (5), 331-336.

[30] Anumudu, C. M., Afolami, C., Igwe, M., Nnwagwu, O., and Keshinro, O. (2008). Nutritional anemia and malaria in pre school and school aged children. Annals of African Medicine, 7 (1), 11-17. 
[31] Hall, A., Bobrow, E, Brooker, S., Jukes, M., Nokes, K., Lambo, J., Guyatt, H, Reandy, D., Adejei, S., Wen, S. T., Subagio, H., Rafiluddin, M. Z., Miguel, T., Moulin, S., de Graft Johnson, J., Mukaka, M., Roschnik, N., Scako, M., Zacher, A., Mahumne, B., Kihamia, C., Mwanri, L., Tatala, S., Lambo, N., Siza, J., Khanh, 1. n, Koi, H. H., and Toan, N. D (2000). Anemia in school children in eight countries in Africa and Asia. Public Health Nutrition, 4 (3), 749-756.

[32] Ukegbu, P. O and Aderibigbe, O. R. (2016). Iron Status, dietary practices and related knowledge among school aged children and their caregivers in Umuahia south local government Area of Abia, State, Nigeria. Nigerian Journal of Nutrition Science. 37 (2): 68-76.

[33] Agugo, U. A, Asinobi C. O and, Afam-Anene O. (2019). Impact of food consumption pattern on the body mass index (BMI) of school children (5-12 years) in selected motherless and orphanage homes in Imo State. Journal of Nutrition Science and Research, Volume 4 (1): 1-5.

[34] Hambidge, K. M., Walravens, P. A, Brown, R. M. (1976). Zinc Nutrition of preschool Children in the Denver head start program. American Journal of Clinical Nutrition, 29 (7), 734738.

[35] Favier, A. E. (1992). Hormonal effects of zinc on growth in children. Biological Trace Element Research, 32, 383-387.

[36] Villalpando, S., Garcia-Guerra, A., Ramirez-Silva, C. I., MejiaRodriguez, F., Matute, G., Shamah-Levy, T., and Rivera, J. A. (2003). Iron, zinc and iodine status in Mexican children under 12 years and women 12-49 years of age. A probabilistic national survey. Salud Publica de Mexico, 45: S520-S529.

[37] Sharifi, F., Hedayati, M., Mirmiran, P. (1999). The serum level of Zinc, $\mathrm{Cu}$, iron in elementary students of 23 province of Iran in 1996. Iran Journal of Endocrine Metabolism. 1 (4): 275-285.

[38] Thurlow, R. A., Winichagoon, P., Pongcharoen, T., Gowachirapant, S., Boonpraderm, A. Manger, M. S., Bailey, K. B., Wasantwisut, E., and Gibson, R. S. (2006). Risk of zinc, iodine and other micronutrient deficiencies among school Children in North East Thailand. European Journal of Clinical Nutrition. 60: 623-632.

[39] Gibson, R. S., McKenzie, J. E, Ferguson, E. L., Parnell, W. R. Wilson, N. C., and Russell, D. G. (2003). The Risk of Inadequate Zinc intake in United States and New Zealand. Adults. Nutrition Today, 38, 63-70.

[40] Golden, B. E. (2013). Infancy, childhood and adolescence. In Human nutrition and Dietetics 10th Edition No. 2, pp. 449464.

[41] Gibson, R. S. (1994). Zinc nutrition in developing countries. Nutrition Research Review, 7 (1), 151-173.

[42] International Zinc Association (2011). Zinc- Natural Occurrence.

http://www.zinc.org/basics/zinc_natural_occurrence. Retrieved 12/11/2018.

[43] Brown, K. H., Peerson, J. M., Rivera, J., and Allen, L. H. (2002). Effect of supplemental zinc on the growth and serum zinc concentrations of prepubertal children: a meta-analysis of randomized controlled trials. American Journal of Clinical Nutrition, 75 (6), 1062-1071.

[44] Fraker, P. J., and King, L. E. (2004). Reprogramming of the immune system during zinc deficiency. Annual Review in Nutrition, 24, 277-98. 